Article

\title{
Responses of Yield and Protein Composition of Wheat to Climate Change
}

\author{
Benyoh Emmanuel Kigha Nsafon ${ }^{1}$, Sang-Chul Lee ${ }^{2}$ and Jeung-Soo Huh ${ }^{1, *}$ \\ 1 Department of Climate Change, College of Engineering, Kyungpook National University, 41566 Daegu, \\ Korea; luxnsafon@yahoo.ca \\ 2 College of Agriculture and Life Sciences, School of Applied Biosciences, Kyungpook National University, \\ 41566 Daegu, Korea; leesc@knu.ac.kr \\ * Correspondence: jshuh@knu.ac.kr; Tel.: +82-53-950-5713
}

Received: 4 February 2020; Accepted: 29 February 2020; Published: 2 March 2020

check for updates

\begin{abstract}
Global wheat demand is expected to continue to increase due to the projected increase in the World's population but regrettably, wheat yield is expected to decrease due to the progressively changing climate. Although the effects of temperature, soil moisture and nutrient absorption on the yield of wheat have been studied extensively to address the threats posed by climate change on food security, the combined effects of these factors have been studied to a lesser extent. This study thus aims to investigate the interactive effects of different regimes of fertilizer and soil moisture on the yield and amino acid composition of wheat. Twelve treatments under different regimens of soil moisture and fertilizer, replicated ten times in a randomized block design were considered in the greenhouse and in the field. The study reveals that variation in each factor had a significant effect on wheat but soil moisture was the principal factor controlling yield and protein accumulation. Application of organic fertilizer to wheat increased amino acid accumulation when the average temperature was at $18{ }^{\circ} \mathrm{C}$, with minimum temperature (Tmin) and maximum temperature (Tmax) of $-6^{\circ} \mathrm{C}$ and $42^{\circ} \mathrm{C}$ respectively. However, application of inorganic fertilizer to wheat enhanced amino acid accumulation when the average daily temperature was at $8{ }^{\circ} \mathrm{C}$, with $\mathrm{Tmin}$ and $\mathrm{Tmax}$ of $-10{ }^{\circ} \mathrm{C}$ and $26{ }^{\circ} \mathrm{C}$ respectively. Our results also show that a decrease in soil moisture from $100 \%$ to $30 \%$ in the greenhouse improved the quantity of amino acid in the grain by $26.4 \%$ and $56.8 \%$ for organic and inorganic treatments respectively. Also, grain amino acid concentration increased by $16.6 \%$ and $4.76 \%$ when soil moisture dropped from $100 \%$ to $30 \%$ for the organic and inorganic treatments in the field respectively.
\end{abstract}

Keywords: wheat; nutrient; soil moisture content; temperature; yield; climate change

\section{Introduction}

Wheat (Triticum spp) is among the first domesticated food crops in the world and it is known to be an important source of protein. According to [1], global wheat consumption is projected to increase by 13\% between 2017 and 2027. Consumption in Sub Saharan Africa is also increasing rapidly and faster than for any other major cereal and it is expected to increase at an even faster rate from 770,000 MT to 1.28 million MT per year between 2020 and 2030 [2]. Regrettably, the progressively changing climate has become a major threat to wheat production and food security [3,4] particularly in sub-Saharan Africa which has been hit the most by climate change, but also at the global level [5]. Thus, wheat yields can be expected to decline markedly [6,7] without the development of suitable management practice for wheat.

Water unavailability, poor crop nutrition and the use of varieties with low yield potential are other factors that threaten wheat production [8,9]. Many empirical studies have confirmed that for 
a particular level of fertility, a reduced amount of soil moisture is associated with an increase in nitrogen content of the plant tissue and a decrease in potassium content [10-13]. Temperature is another factor that plays an important role in wheat production. High temperature would require adequate soil moisture content due to high rate of evapotranspiration. At a very low temperature, the plant root is cooled and the nutrient uptake capacity of the plant is reduced compared to warmer roots. Referring to [14], the time of high temperature during grain-filling is very important, and has a specific effect on grain quality through the accumulation of protein in the wheat grain.

However, the collective effect of irrigation along with nutrition and variety can play a vital role in increasing wheat productivity [15]. The combined use of nitrogen, phosphorus and potassium (NPK) fertilizers can play an important role in increasing yield and quality of wheat. Even though there have been numerous studies on the influence of temperature, fertilizer and soil moisture on growth and yield of wheat, we are not aware of any studies that attempt to combine different regimens of all three factors in one experiment. Reference [16] investigated the effects of increased fertilizer application to wheat under high temperature without any explanation on how different levels of soil moisture could affect yield. References [17-19] also focused on the combined effects of soil moisture content and fertilizer on wheat without recognizing the additional role of temperature on yield.

Moreover, most studies comparing the response of wheat to the combined effects of water and moisture do not analyze different regimes of all two factors in a single experiment [20,21]. Consequently, the objective of this work is to investigate the relative importance of wheat performance under different regimes of fertilizer and soil moisture in the greenhouse and field, in order to understand the interactive effects of these factors on the yield and amino acid content of wheat.

\section{Materials and Methods}

\subsection{Experimental Site}

The study was conducted at the experimental site of the College of Agriculture and Life Sciences, Kyungpook National University in South Korea, to evaluate the effects of fertilizer and soil moisture on the growth of "Baegjoong" wheat cultivar in the greenhouse and field conditions.

\subsection{Treatments Application and Planting}

Plants were subjected to different regimes of fertilizer and soil moisture in the greenhouse covered with polyethylene film, and in the field: (1) Fertilizer: organic and inorganic fertilizers; (2) Water: 30\%, $60 \%$ and $100 \%$ moisture levels. The details of the treatment application are presented in Table 1.

Table 1. Treatments application.

\begin{tabular}{cccccccc}
\hline \multirow{2}{*}{ Treatment } & \multicolumn{2}{c}{ Growth Condition } & \multicolumn{2}{c}{ Fertilizer Type } & \multicolumn{3}{c}{ Soil Moisture Content (\%) } \\
\cline { 2 - 8 } & Greenhouse & Field & Organic & Inorganic & $\mathbf{3 0}$ & $\mathbf{6 0}$ & $\mathbf{1 0 0}$ \\
\hline T1 & $\checkmark$ & - & $\checkmark$ & - & $\checkmark$ & - & \\
T2 & $\checkmark$ & - & $\checkmark$ & - & - & $\checkmark$ & \\
T3 & $\checkmark$ & - & $\checkmark$ & - & - & - & $\checkmark$ \\
T4 & $\checkmark$ & - & - & $\checkmark$ & $\checkmark$ & - & - \\
T5 & $\checkmark$ & - & - & $\checkmark$ & - & - & $\checkmark$ \\
T6 & $\checkmark$ & - & - & $\checkmark$ & - & - & - \\
T7 & - & $\checkmark$ & $\checkmark$ & - & $\checkmark$ & - & $\checkmark$ \\
T8 & - & $\checkmark$ & $\checkmark$ & - & - & - & - \\
T9 & - & $\checkmark$ & $\checkmark$ & - & - & - & - \\
T10 & - & $\checkmark$ & - & $\checkmark$ & $\checkmark$ & - \\
T11 & - & $\checkmark$ & - & $\checkmark$ & - & - & $\checkmark$ \\
T12 & - & $\checkmark$ & - & $\checkmark$ & - & \\
\hline
\end{tabular}


The greenhouse treatment was performed under a controlled temperature regime (Figure 1), while the field treatment was performed under ordinary daily temperature (Figure 2). Tmin (minimum temperature) and $T \max$ (maximum temperature) from sowing to the start of heading were at $-6^{\circ} \mathrm{C}$ and $26^{\circ} \mathrm{C}$ respectively. From heading to physiological maturity, Tmin and Tmax in the greenhouse were at $-6{ }^{\circ} \mathrm{C}$ and $42{ }^{\circ} \mathrm{C}$ respectively. Tmax at $42{ }^{\circ} \mathrm{C}$ was maintained throughout the heading, anthesis, and physiological maturity stages. Tmin and Tmax before the heading stage in the field were at $-10^{\circ} \mathrm{C}$ and $15^{\circ} \mathrm{C}$ respectively. Tmin increased to $-3{ }^{\circ} \mathrm{C}, 8{ }^{\circ} \mathrm{C}$ and $13{ }^{\circ} \mathrm{C}$ throughout the heading, anthesis and maturity stages, respectively. Tmax also increased to $17^{\circ} \mathrm{C}, 19^{\circ} \mathrm{C}$ and $26^{\circ} \mathrm{C}$ during the heading, anthesis and maturity stages, respectively.

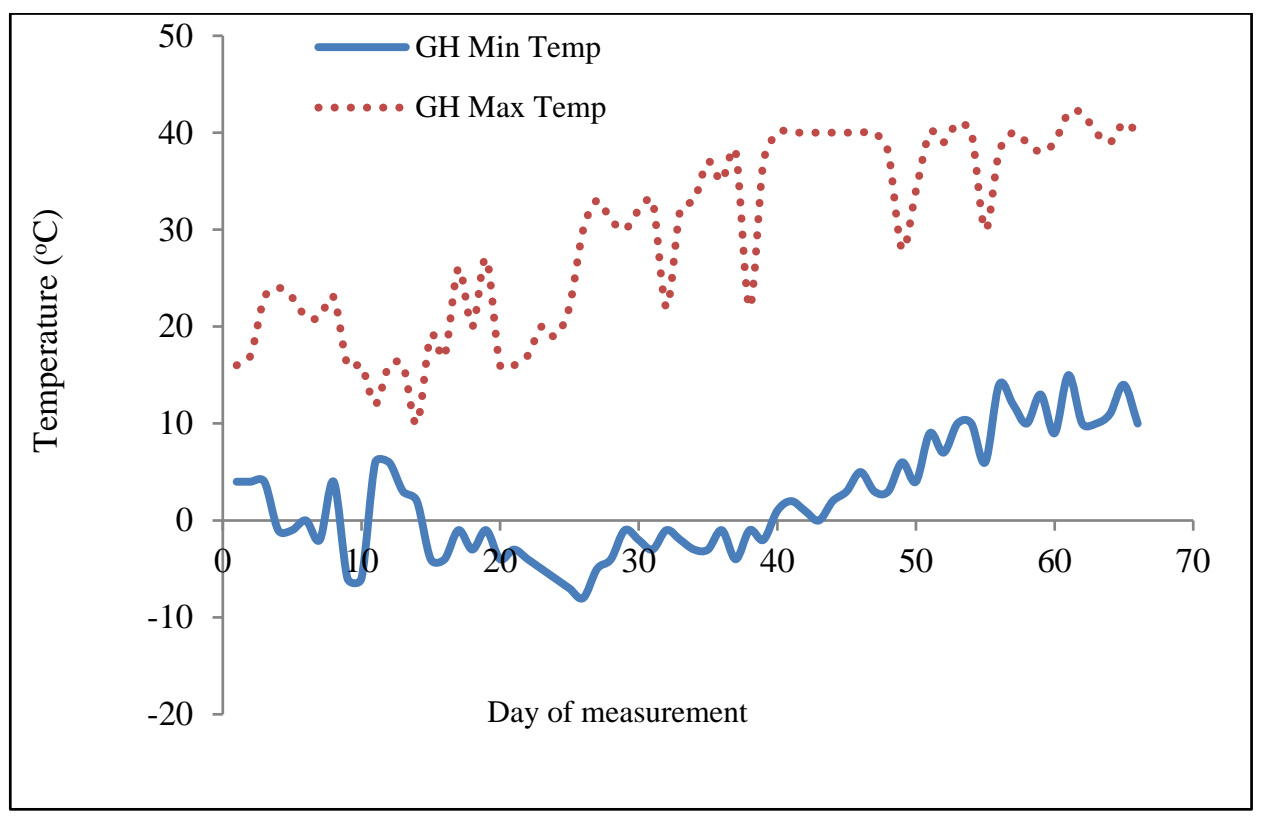

Figure 1. Minimum and maximum temperature in the greenhouse with respect to day of measurement. GH: Greenhouse.

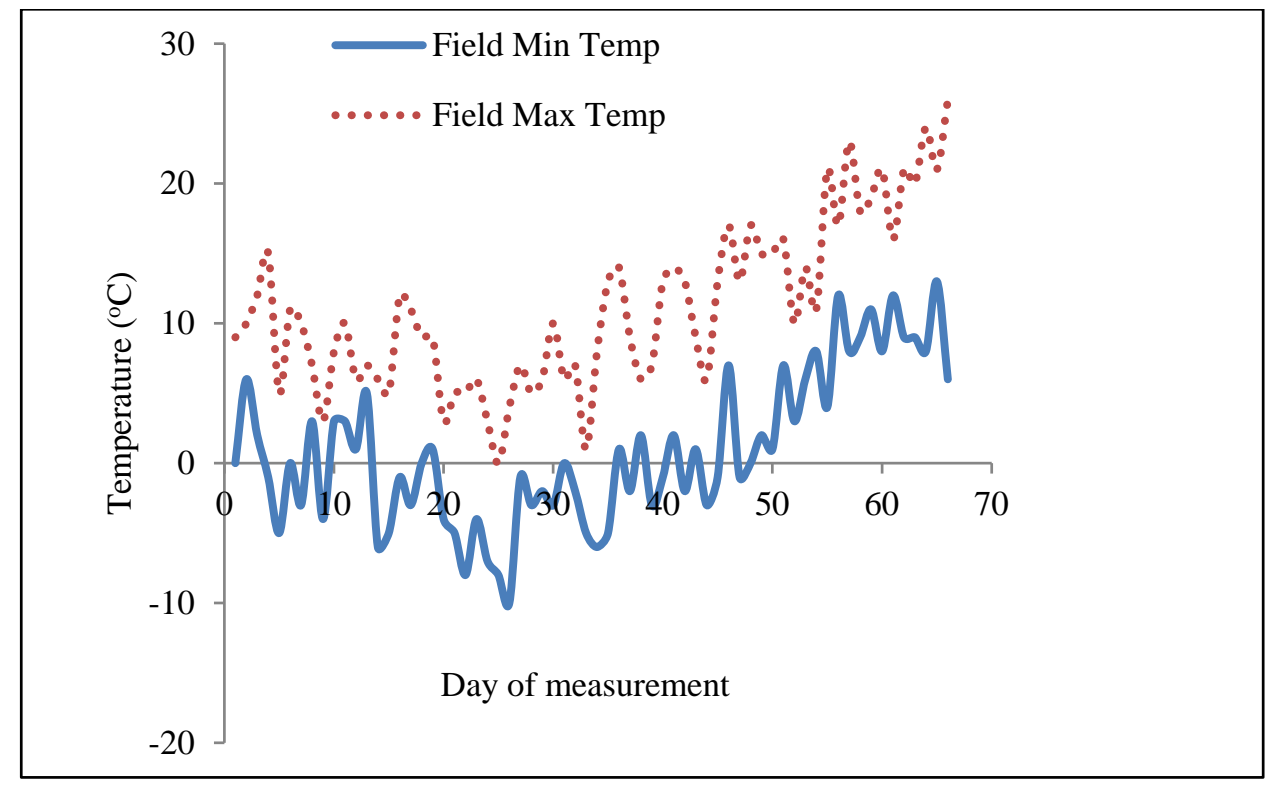

Figure 2. Minimum and maximum temperature in the field with respect to day of measurement. 
A range of nitrogen $(1.52 \mathrm{~g})$, phosphorus $(3.53 \mathrm{~g})$ and potassium $(0.75 \mathrm{~g})$ fertilizer was applied per pot. Full doses of phosphorus, potassium and half dose of nitrogen $(0.76 \mathrm{~g})$ were applied per pot before sowing for the inorganic treatment, and the remaining half dose of $\mathrm{N}(0.76 \mathrm{~g})$ was then top dressed at heading stage. Three hundred and fifty g of compost organic fertilizer $(1.31 \% \mathrm{~N}, 1.94 \% \mathrm{P}$ and $1.99 \% \mathrm{~K})$ containing $70 \%$ wood, $25 \%$ plant and $5 \%$ fecal matter was also applied per pot once before planting for the organic treatment.

Twelve treatments replicated ten times were considered in this experiment (Table 1). Four wheat seeds were sown $(15 \mathrm{~cm}$ apart $\times 2 \mathrm{~cm}$ deep) per pot $(30 \mathrm{~cm}$ diameter $\times 20 \mathrm{~cm}$ deep) with two seeds per hole. Pots spacing within the rows was at $30 \mathrm{~cm}$ to allow for stress-free movement during water treatment and easy collection of data. After planting, all pots were treated with $100 \%$ soil moisture content but not waterlogged until the day of three leaflets. Treating all pots at $100 \%$ moisture was to ensure proper germination of the seed as this stage is one of the most important life-stages of a plant. Plants were then watered twice daily at 6:00 am and 6:00 pm according to our treatments until the research was terminated. Soil moisture levels were measured each time before irrigation using a soil moisture sensor (WET Sensor Kit WET-2-K1) to determine how much water is required by each pot.

\subsection{Experimental Design}

The pots were arranged in a randomized complete block design (RCBD) with 10 single-treatment replications.

\subsection{Measurement of Temperature and Yield Components}

Air temperature in the greenhouse and field conditions was recorded at two days intervals using a thermometer. Max, min and daily average temperatures (Figures 1-3) were determined for each day of measurement using the Six's Maximum and Minimum thermometer and a data logger. Plant height was measured from the base of the pot with a line gauge and tiller number per hole was also counted. We counted the tiller number per hole because we could not differentiate the stems of the two seeds that were sown in each hole. Records on plant height and tiller number were taken after every ten days from the day of seedling until growth stopped. At physiological maturity, plants were then off-rooted and weighed using an electronic scale (All-in-1 Series, ACCUTECK). Three panicles per pot with a total of thirty panicles per treatment were randomly chosen for the measurement of panicle length. The average length was then calculated to have the panicle length for each treatment. Panicles were then rumpled gently, and records on the number of grains panicle ${ }^{-1}$ and grain weight panicle ${ }^{-1}$ for each treatment were collected. The yield was then calculated by measuring the grain weight plant ${ }^{-1}$ for each treatment. 


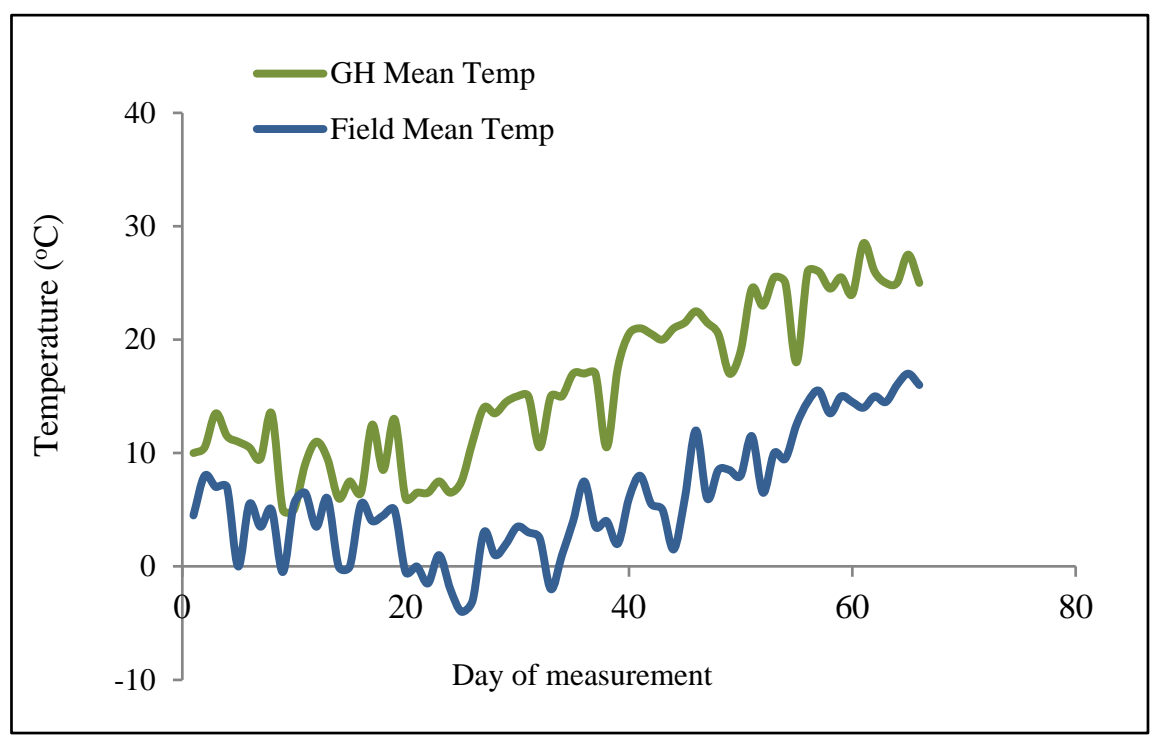

Figure 3. Mean temperature in the greenhouse and field with respect to day of measurement. GH: Greenhouse.

\subsection{Amino Acid Analysis}

The concentration of free amino acids was determined by an amino acid analyzer (L8900, Hitachi, Tokyo, Japan). The following steps were involved: 1 milliliter of $6 \mathrm{~N} \mathrm{HCl}$ was poured into $0.05 \mathrm{~g}$ of sample in the glass vial. The sample was then charged with nitrogen gas to remove air and then tightly capped. The sample was hydrolyzed at $110{ }^{\circ} \mathrm{C}$ for $24 \mathrm{~h}$. After hydrolysis, the sample was allowed to cool for $30 \mathrm{~min}$. The cap was then opened and the sample dried at $80^{\circ} \mathrm{C}$ for $24 \mathrm{~h}$. After cooling for $30 \mathrm{~min}, 1$ milliliter of $0.02 \mathrm{~N} \mathrm{HCl}$ was added to the sample in the vial and then extracted by sonication-vortex method. The ample was filtered by $0.45 \mathrm{um}$ cellulose acetate membrane filter and then diluted with $0.02 \mathrm{~N} \mathrm{HCl}$ after filtration. The separated amino acids were reacted with ninhydrin acids and detected at $570 \mathrm{~nm}$ except for proline, which was detected at $440 \mathrm{~nm}$.

\subsection{Analysis of Variance (ANOVA)}

The collected data was analyzed statistically by the analysis of variance technique using SPSS version 22. T-test for equality of means was used for data with two factors. For experiments that require the evaluation of all possible pairs treatment means, the Duncan Multiple Range Test (DMRT) test is recommended [22]. DMRT test was applied for data with more than two factors at $5 \%$ probability level, to test the significance of treatments means. $P<0.05$ was taken to indicate statistical significance.

\section{Results and Discussion}

\subsection{Organic and Inorganic Fertilizers}

In Table 2, all the data from greenhouse and field were pooled. The result showed that fertilizer type had no significant impact on plant height, tiller number hole ${ }^{-1}$, plant weight, panicle length and the number of grains panicle ${ }^{-1}$ but a significant impact on grain weight panicle ${ }^{-1}$, grain yield plant ${ }^{-1}$ and harvest index at $5 \%$ probability level.

Inorganic fertilizer produced a higher plant height $(73.60 \mathrm{~cm})$, tiller number hole ${ }^{-1}(11)$, plant weight $(17.30 \mathrm{~g})$, panicle length $(7.22 \mathrm{~cm})$, number of grains panicle ${ }^{-1}(29.3)$, grain weight panicle $^{-1}(1.1 \mathrm{~g})$, grain yield plant ${ }^{-1}(6.29 \mathrm{~g})$ and harvest index $(37 \%)$ than the organic fertilizer $(73.55 \mathrm{~cm}, 10,16.55 \mathrm{~g}, 7.16 \mathrm{~cm}, 25.8,1.0,4.81 \mathrm{~g}$ and $30 \%$, respectively). This is because inorganic fertilizers are known to have the uniqueness of fast release of their nutrient contents. The remaining half dose of nitrogen $(0.76 \mathrm{~g})$ that was top-dressed at the heading stage significantly produced a longer 
panicle length for the inorganic treatment. The longer panicle length in turn increased the number of grains panicle $^{-1}$ and grain weight panicle ${ }^{-1}$. According to [23], the release of nutrients from organic fertilizer is slow compared to inorganic fertilizer. Consequently, nutrients were not readily available throughout the growing period for organic treatment. Also, leaching possibly might have occurred since organic fertilizer was applied only one time before planting. Although the yield plant ${ }^{-1}$ for the inorganic treatment was $13.3 \%$ better than that for the organic treatment, the continuous use of these fertilizers can however cause a decrease in crop yield over time. Excessive use of chemical fertilizer can cause serious soil degradation through nitrogen leaching and reduction in soil organic matter, and consequently decrease in crop yield over time [24]. Therefore, the combined use of chemical fertilizer and organic matter is recommended to enhance soil fertility and increase the yield of crops [25].

\subsection{Fertilizer and Soil Moisture}

It is prominent that adequate water in the soil allows efficient uptake of nutrients by the plant. According to [26], yield and yield components of plants in drying soil are reduced even in tolerant genotypes and soil moisture affects the growth of tillers, while grain yield depends on number of tillers, spike length, seed per ear and grain size. In Table 3, all the data from greenhouse and field were pooled. It was noted that tiller number amongst all yield components did not have a significant difference under different regimes of fertilizer and soil moisture at $5 \%$ probability level.

The highest plant height $(79.0 \mathrm{~g})$, tiller number hole ${ }^{-1}(12)$, plant weight $(21.49 \mathrm{~g})$, panicle length $(7.60 \mathrm{~cm})$, number of grains panicle ${ }^{-1}(38)$, grain weight panicle ${ }^{-1}(1.35 \mathrm{~g})$, grain yield plant ${ }^{-1}(8.07 \mathrm{~g})$ and harvest index (38\%) were observed in the treatment with inorganic fertilizer and $100 \%$ moisture content. Reference [27] also noticed that, the application of irrigation increased grain and straw yield, number of tiller and thousand kernel weights. Treatment with organic fertilizer and 30\% moisture content had the lowest plant height $(68.05 \mathrm{~cm})$, tiller number hole ${ }^{-1}(9)$, plant weight $(11.98 \mathrm{~g})$, number of grains panicle $\mathrm{e}^{-1}(2)$, grain weight panicle ${ }^{-1}(0.87 \mathrm{~g})$, grain yield plant ${ }^{-1}(3.09 \mathrm{~g})$ and harvest index $(28 \%)$. The lowest panicle length $(6.78 \mathrm{~cm})$ was observed in the treatment with inorganic fertilizer and $30 \%$ soil moisture. The poorest yield and yield components were noticed in the treatment with $30 \%$ soil moisture because plants experienced drought stress. Reference [28] observed this type of performance in their work.

Moreover, [29] pointed out that $\mathrm{N}$ fertilization reduces grain yield in unirrigated plots by decreasing the number of heads, apparently by increasing the moisture stress of the plant. Reference [30] also witnessed moisture stress and reduced dry matter production for plants receiving more $\mathrm{N}$ fertilizer under dryland conditions by anthesis. Consequently, the reduced yield and plant weight seen in the treatment with 30\% soil moisture and inorganic $\mathrm{N}$ fertilization during the heading stage confirms previous studies. However, the yield plant $^{-1}$ for wheat with $30 \%$ soil moisture and inorganic fertilizer was better than wheat treated with $30 \%$ soil moisture and organic fertilizer. Grain yield plant ${ }^{-1}$ for wheat treated under $100 \%$ soil moisture was $15.1 \%$ and $26.7 \%$ better than the yield for wheat treated under $60 \%$ and $30 \%$ moisture treatments, respectively.

\subsection{Growth Condition, Fertilizer Type and Soil Moisture Content}

This research revealed that the interactive effects of fertilizer and soil moisture were significant on yield and all yield components of wheat in the greenhouse and field at 5\% probability level (Table 4). T6 produced the largest tiller number hole ${ }^{-1}(15)$, plant height $(82.00 \mathrm{~cm})$, plant weight $(26.46 \mathrm{~g})$, grain weight panicle ${ }^{-1}(1.4 \mathrm{~g})$ and grain yield plant $^{-1}(9.56 \mathrm{~g})$ because during the germination, tillering and stem elongation stages, the average temperature in the greenhouse was at $10^{\circ} \mathrm{C}$, whereas the average temperature in the field was at $2.7^{\circ} \mathrm{C}$. Warming in the greenhouse made wheat to attain physiological maturity 15 days earlier than wheat in the field. Agreeing with [31], wheat grew faster under warming temperature during re-greening, and this advantage was maintained till maturity. $\mathrm{T} 12$ also produced the best panicle length $(8.41 \mathrm{~cm})$, number of grains panicle ${ }^{-1}(41.5)$ and harvest index $(40 \%)$ because at the time of panicle growth and grain filling stage, the temperature in the field had risen 
to $19^{\circ} \mathrm{C}$, whereas the greenhouse had a temperature of $42{ }^{\circ} \mathrm{C}$. According to [32], high temperatures during grain filling may reduce the grain growth period by shortening the duration of photosynthetic tissue. Since high temperatures shortened the duration of photosynthesis in our research, the amount of carbohydrate available for panicle growth was also reduced. This result tie with that of $[14,33]$ also noted that the maximum temperature during the grain-filling stage for wheat lies between 33.4 and $37.4{ }^{\circ} \mathrm{C}$. The results observed in $\mathrm{T} 6$ and $\mathrm{T} 12$ was also because the inorganic source of NPK fertilizer was readily released. Additionally, the readily available fertilizer was easily absorbed by plants treated with 100\% soil moisture. The uptake of nutrients by plants in T6 enhanced growth of stems, tillering, grain weight and consequently, best yield plant $^{-1}$. T12 had the highest number of grains panicle ${ }^{-1}$ because Tmax of $19^{\circ} \mathrm{C}$ in the field was favorable for grain filling. This result ties with that of [33], who revealed that the optimal and maximum temperature required for grain filling should be $20^{\circ} \mathrm{C}$ and $35^{\circ} \mathrm{C}$ respectively. Reference [34] also noted in their study that, increase in grain number per ear is the result of fertilized spikes which is determined by moisture levels that influence nutrient uptake. Our result in T6 (largest plant height and tiller number hole ${ }^{-1}$ ) is in line with that of [35].

T7 had the least tiller number hole ${ }^{-1}(5)$, plant weight $(8.02 \mathrm{~g})$ and grain yield plant $^{-1}(2.48 \mathrm{~g})$, whereas, T1 had the least grain weight panicle ${ }^{-1}(0.85 \mathrm{~g})$, number of grains panicle ${ }^{-1}(17.2)$ and harvest index $(23 \%) . \mathrm{T} 4$ and T10 also had the least panicle length $(6.62 \mathrm{~cm})$ and plant height $(66.80 \mathrm{~cm})$, respectively. Reference [36] also found the corresponding decrease in the number of tillers with dryland. The least plant weight (T7) and plant height (T10) for plant treated with 30\% moisture content in the field were observed because the soil moisture content $(30 \%)$ and $\mathrm{Tmin}$ of $-10{ }^{\circ} \mathrm{C}$ at the early growth stage were not suitable for stem elongation. Referring to [37] temperature is a key factor that affects plant development and preceding studies [38] confirmed that, irrespective of how favorable light and moisture content may be, plant growth stops when the temperature drops below a certain minimum value. Further, wheat phenology and fertility of pollen grains during the reproductive phase are also affected by low temperature leading to the reduction in wheat yield [39]. The average field temperature at $2.7^{\circ} \mathrm{C}$ was also low for the stem elongation and tillering stages. This consequently led to a reduced number of panicles plant ${ }^{-1}$ and consequently a decrease in yield plant ${ }^{-1}$. This confirms the work of [40] who stated that $T \mathrm{~min}$ of $4{ }^{\circ} \mathrm{C}$ is required from sowing to emergence in wheat. T4 had the worst panicle length, while T1 had the least number of grains panicle ${ }^{-1}$ and weight of grain panicle ${ }^{-1}$. This is because both treatments had the lowermost soil moisture content $(30 \%)$ and combined with rising temperature $\left(42^{\circ} \mathrm{C}\right)$, the efficiency of nutrient uptake was reduced at the heading stage. Although T12 produced the best panicle length, number of grains panicle ${ }^{-1}$ and harvest index, the overall best yield plant ${ }^{-1}$ was witnessed in $\mathrm{T} 6$. This is because $T \min \left(-4{ }^{\circ} \mathrm{C}\right.$ to $\left.6{ }^{\circ} \mathrm{C}\right)$ and $T \max \left(16^{\circ} \mathrm{C}\right.$ to $\left.26^{\circ} \mathrm{C}\right)$ during the early vegetative stage in $\mathrm{T} 6$ was suitable for tillering. This in turn produced the highest tiller number plant $^{-1}$, grain number panicle ${ }^{-1}$, grain weight panicle ${ }^{-1}$ and consequently the best yield plant ${ }^{-1}$. 
Table 2. Mean comparison of growth and yield components of wheat under different types of fertilizers.

\begin{tabular}{|c|c|c|c|c|c|c|c|c|}
\hline Treatment & $\begin{array}{c}\text { Plant } \\
\text { Height }(\mathrm{cm})\end{array}$ & $\begin{array}{c}\text { Tiller } \\
\text { Number Hole }^{-1}\end{array}$ & $\begin{array}{c}\text { Plant } \\
\text { Weight (g) }\end{array}$ & $\begin{array}{c}\text { Panicle } \\
\text { Length }(\mathrm{cm})\end{array}$ & $\begin{array}{c}\text { Grain Number } \\
\text { Panicle }^{-1}\end{array}$ & $\begin{array}{l}\text { Grain Weight } \\
\text { Panicle }^{-1} \text { (g) }\end{array}$ & $\begin{array}{l}\text { Grain Yield } \\
\text { Plant }^{-1}(g)\end{array}$ & $\begin{array}{c}\text { Harvest } \\
\text { Index (\%) }\end{array}$ \\
\hline Organic & $73.55^{a}$ & $10.00^{\mathrm{a}}$ & $16.55^{\mathrm{a}}$ & $7.16^{\mathrm{a}}$ & $25.80^{\mathrm{a}}$ & $1.00^{\mathrm{b}}$ & $4.81^{\mathrm{b}}$ & $30.00^{b}$ \\
\hline Inorganic & $73.60^{a}$ & $11.00^{\mathrm{a}}$ & $17.30^{\mathrm{a}}$ & $7.22^{a}$ & $29.30^{a}$ & $1.10^{\mathrm{a}}$ & $6.29^{a}$ & $36.00^{\mathrm{a}}$ \\
\hline
\end{tabular}

Means followed by the same letter in a column are not significantly different at the $5 \%$ level based on T-test for equality of means.

Table 3. Mean comparison of growth and yield components of wheat under different regimes of fertilizer and soil moisture.

\begin{tabular}{|c|c|c|c|c|c|c|c|c|}
\hline Treatment & $\begin{array}{c}\text { Plant } \\
\text { Height }(\mathrm{cm})\end{array}$ & $\begin{array}{c}\text { Tiller } \\
\text { Number Hole }^{-1}\end{array}$ & $\begin{array}{c}\text { Plant } \\
\text { Weight (g) }\end{array}$ & $\begin{array}{l}\text { Panicle Length } \\
(\mathrm{cm})\end{array}$ & $\begin{array}{l}\text { Grain Number } \\
\text { Panicle }^{-1}\end{array}$ & $\begin{array}{l}\text { Grain Weight } \\
\text { Panicle }^{-1}(\mathrm{~g})\end{array}$ & $\begin{array}{l}\text { Grain Yield } \\
\text { Plant }^{-1}(\mathrm{~g})\end{array}$ & $\begin{array}{l}\text { Harvest Index } \\
(\%)\end{array}$ \\
\hline $\mathrm{O} 30$ & $68.05^{c}$ & $9.00^{\mathrm{a}}$ & $11.98^{\mathrm{d}}$ & 6.91 de & $20.40^{\mathrm{d}}$ & $0.87^{c}$ & $3.09^{c}$ & $26.00^{c}$ \\
\hline $\mathrm{O} 60$ & $74.05^{b}$ & $11.00^{\mathrm{a}}$ & $17.17^{b c}$ & $7.11^{\mathrm{cd}}$ & $24.50^{\mathrm{cd}}$ & $0.95^{c}$ & $4.92 \mathrm{bc}$ & $29.00^{c}$ \\
\hline $\mathrm{I} 30$ & $67.30^{c}$ & $10.00^{a}$ & $13.73^{\mathrm{cd}}$ & $6.78^{\mathrm{e}}$ & $22.40^{\mathrm{cd}}$ & $0.95^{c}$ & $4.56^{\mathrm{bc}}$ & $33.00^{b}$ \\
\hline $\mathrm{I} 60$ & $74.50^{\mathrm{b}}$ & $11.00^{\mathrm{a}}$ & $16.67^{b c}$ & $7.29 b^{c}$ & $27.70 \mathrm{bc}$ & $1.10^{\mathrm{b}}$ & $6.23^{b}$ & $37.00^{\mathrm{a}}$ \\
\hline I100 & $79.00^{\mathrm{a}}$ & $12.00^{\mathrm{a}}$ & $21.49^{a}$ & $7.60^{\mathrm{a}}$ & $37.90^{\mathrm{a}}$ & $1.35^{\mathrm{a}}$ & $8.07^{a}$ & $38.00^{\mathrm{a}}$ \\
\hline
\end{tabular}

Post Hoc Tests: Duncan multiple comparison. Values followed by the same letter in a column are not significantly different $(p<0.05)$. O30: Organic fertilizer $+30 \%$ soil moisture content;

O60: Organic fertilizer + 60\% soil moisture content; O100: Organic fertilizer + 100\% soil moisture content; I30: Inorganic fertilizer + 30\% soil moisture content; I60: Inorganic fertilizer +

$60 \%$ soil moisture content; I100: Inorganic fertilizer + $100 \%$ soil moisture content. 
Table 4. Summarized effects of temperature, fertilizer and soil moisture on yield attributes of wheat.

\begin{tabular}{|c|c|c|c|c|c|c|c|c|}
\hline Treatment & $\begin{array}{c}\text { Plant } \\
\text { Height }(\mathrm{cm})\end{array}$ & $\begin{array}{c}\text { Tiller } \\
\text { Number Hole }^{-1}\end{array}$ & $\begin{array}{c}\text { Plant } \\
\text { Weight (g) }\end{array}$ & $\begin{array}{l}\text { Panicle Length } \\
\text { (cm) }\end{array}$ & $\begin{array}{c}\text { Grain Number } \\
\text { Panicle }^{-1}\end{array}$ & $\begin{array}{l}\text { Grain Weight } \\
\text { Panicle }^{-1}(\mathrm{~g})\end{array}$ & $\begin{array}{l}\text { Grain Yield } \\
\text { Plant }^{-1}(\mathrm{~g})\end{array}$ & $\begin{array}{l}\text { Harvest } \\
\text { Index }\end{array}$ \\
\hline $\mathrm{T} 1$ & $68.80^{c}$ & $13.00^{b}$ & $15.94 \mathrm{de}$ & $7.07^{\text {def }}$ & $17.20^{\mathrm{f}}$ & $0.85^{\mathrm{d}}$ & 3.72 fgh & $23.00^{\mathrm{e}}$ \\
\hline $\mathrm{T} 2$ & $75.20^{b}$ & $14.00^{\mathrm{ab}}$ & $21.65^{b}$ & 7.034 ef & 21.00 ef & $0.96^{\mathrm{bcd}}$ & 5.65 de & $26.00^{\text {de }}$ \\
\hline $\mathrm{T} 4$ & $67.80^{\mathrm{c}}$ & $14.00^{\mathrm{ab}}$ & $19.25 \mathrm{bc}$ & $6.62 \mathrm{~g}$ & $17.80^{\mathrm{f}}$ & $0.93^{\mathrm{cd}}$ & $6.13^{\mathrm{cd}}$ & $32.00 \mathrm{bcd}$ \\
\hline T5 & $76.20^{\mathrm{b}}$ & $14.00^{\mathrm{ab}}$ & $20.87^{b}$ & $6.71^{\mathrm{fg}}$ & 25.20 de & $1.09 \mathrm{bc}$ & $7.47^{b}$ & $36.00 \mathrm{ab}$ \\
\hline T6 & $82.00^{a}$ & $15.00^{\mathrm{a}}$ & $26.46^{\mathrm{a}}$ & $6.80^{\mathrm{efg}}$ & $34.20 \mathrm{bc}$ & $1.40^{\mathrm{a}}$ & $9.56^{\mathrm{a}}$ & $36.00 \mathrm{ab}$ \\
\hline $\mathrm{T} 7$ & $67.30^{c}$ & $5.00^{\mathrm{e}}$ & $8.02^{g}$ & $6.74 \mathrm{fg}$ & 23.70 def & $0.90^{\mathrm{d}}$ & $2.48^{\mathrm{h}}$ & 31.00 bcde \\
\hline T9 & $75.80^{\mathrm{b}}$ & $8.90^{c}$ & 14.91 def & $7.38^{\mathrm{cd}}$ & $36.10^{a b}$ & $1.11^{\mathrm{b}}$ & 5.67 de & $38.00^{a b}$ \\
\hline $\mathrm{T} 10$ & $66.80^{c}$ & $5.90 \mathrm{de}$ & $8.21^{g}$ & 6.94 efg & 27.00 de & $0.96^{\mathrm{bcd}}$ & $2.95 \mathrm{gh}$ & $36.00^{a b}$ \\
\hline $\mathrm{T} 11$ & $72.80^{\mathrm{b}}$ & $7.00^{\mathrm{cd}}$ & $12.47^{\mathrm{f}}$ & $7.87^{b}$ & $30.20^{b c d}$ & $1.11^{\mathrm{b}}$ & 4.67 ef $^{-1}$ & $37.00^{\mathrm{ab}}$ \\
\hline $\mathrm{T} 12$ & $76.00^{\mathrm{b}}$ & $8.00^{c}$ & $16.52^{\mathrm{cd}}$ & $8.41^{\mathrm{a}}$ & $41.50^{\mathrm{a}}$ & $1.30^{\mathrm{a}}$ & $6.58^{\mathrm{bcd}}$ & $40.00^{a}$ \\
\hline
\end{tabular}

Post Hoc Tests: Duncan multiple comparison. Values followed by the same letter in a column are not significantly different $(p<0.05)$. 


\subsection{Amino Acid Content of Wheat Grain}

The amino acid composition of wheat was intensively affected by different regimes of fertilizer and soil moisture. Wheat treated with T10 and T6 had the best and least total amino acid content respectively (Table 5).

Table 5. Amino acid composition of wheat grain under different regimes of temperature, fertilizer type and soil moisture content.

\begin{tabular}{ccccccccccccc}
\hline $\begin{array}{c}\text { Amino Acids } \\
\text { (mg/g) }\end{array}$ & $\mathbf{T 1}$ & $\mathbf{T 2}$ & $\mathbf{T 3}$ & $\mathbf{T 4}$ & $\mathbf{T 5}$ & $\mathbf{T 6}$ & $\mathbf{T 7}$ & $\mathbf{T 8}$ & $\mathbf{T 9}$ & $\mathbf{T 1 0}$ & $\mathbf{T 1 1}$ & $\mathbf{T 1 2}$ \\
\hline Aspartic acid & 4.497 & 3.543 & 3.027 & 4.047 & 3.124 & 0.889 & 2.048 & 1.731 & 1.734 & 5.692 & 4.678 & 4.262 \\
Threonine & 2.471 & 1.852 & 1.529 & 2.149 & 1.584 & 0.264 & 0.770 & 0.609 & 0.638 & 3.723 & 2.229 & 2.034 \\
Serine & 2.775 & 2.086 & 1.673 & 2.469 & 1.741 & 0.334 & 0.720 & 0.599 & 0.729 & 3.865 & 2.308 & 2.092 \\
Glutamic acid & 26.983 & 18.835 & 13.905 & 23.609 & 14.458 & 1.988 & 6.883 & 3.926 & 5.665 & 25.434 & 23.514 & 23.217 \\
Glycine & 2.319 & 1.586 & 1.216 & 1.827 & 1.214 & 0.140 & 0.257 & 1.283 & 0.262 & 2.827 & 1.245 & 1.095 \\
Alanine & 5.301 & 4.345 & 3.849 & 4.939 & 4.075 & 2.916 & 5.148 & 4.592 & 3.638 & 8.246 & 6.958 & 6.764 \\
Cystine & 0.832 & 0.549 & 0.428 & 0.664 & 0.434 & 0.397 & 0.561 & 0.511 & 0.480 & 0.732 & 0.864 & 0.781 \\
Valine & 5.265 & 4.088 & 3.431 & 4.729 & 3.586 & 1.971 & 3.598 & 3.184 & 2.614 & 5.997 & 5.579 & 5.517 \\
Methionine & 1.257 & 0.928 & 0.772 & 1.025 & 0.778 & 0.188 & 0.544 & 0.460 & 0.338 & 1.001 & 1.199 & 1.124 \\
Isoleucine & 4.530 & 3.346 & 2.715 & 3.998 & 2.843 & 1.512 & 2.955 & 2.627 & 1.965 & 4.215 & 4.666 & 4.604 \\
Leucine & 8.457 & 6.258 & 5.045 & 7.536 & 5.294 & 2.162 & 4.872 & 4.256 & 3.226 & 7.569 & 8.588 & 8.435 \\
Tyrosine & 2.476 & 1.811 & 1.398 & 2.199 & 1.422 & 0.568 & 1.502 & 1.345 & 0.974 & 2.759 & 3.278 & 3.197 \\
Phenylalanine & 5.315 & 3.738 & 2.937 & 4.808 & 3.100 & 1.037 & 2.684 & 2.335 & 1.787 & 4.692 & 5.415 & 5.296 \\
Lysine & 2.410 & 1.949 & 1.765 & 2.102 & 1.806 & 0.247 & 0.606 & 0.502 & 0.646 & 1.489 & 1.916 & 1.760 \\
Ammonia & 4.052 & 2.994 & 2.357 & 3.658 & 2.496 & 2.817 & 4.025 & 3.631 & 2.577 & 5.517 & 5.429 & 4.996 \\
Histidine & 2.476 & 1.805 & 1.425 & 2.166 & 1.498 & 0.423 & 1.000 & 0.827 & 0.673 & 2.894 & 2.487 & 2.231 \\
Arginine & 4.841 & 3.798 & 3.276 & 4.385 & 3.409 & 1.532 & 2.988 & 2.546 & 2.197 & 4.228 & 4.956 & 4.808 \\
Proline & 11.280 & 8.018 & 6.087 & 10.240 & 6.412 & 4.441 & 8.081 & 7.323 & 5.094 & 13.493 & 12.985 & 12.666 \\
Total amino & 97.54 & 71.53 & 56.84 & 86.55 & 59.23 & 23.83 & 49.24 & 42.29 & 35.24 & 104.37 & 98.29 & 94.88 \\
$\quad$ acid & & & & & & & & & & & & \\
\hline
\end{tabular}

The amino acid content in wheat grain increased with decreasing soil moisture at the detriment of grain yield [41-43]. Similarly, [44] reported increased protein content of wheat with high moisture stress and nitrogen fertilization. Reference [45] also noticed in their work that soil moisture more strongly influenced the nitrogen content of wheat grain than available nitrogen in the soil. The low protein content in wheat grains as a result of high moisture content (T6) was caused by yield dilution effects on grain protein [46]. Also, low protein content of high yield lines (T10) was caused by either a limited amount of protein deposited in a large number of kernels, or it was a result of a limited amount of proteins diluted by a larger mass of carbohydrates [47]. In this research, a decrease in soil moisture from $100 \%$ to $30 \%$ in the greenhouse enhanced the quantity of amino acid in the grain by $26.4 \%$ and $56.8 \%$ for organic and inorganic treatments respectively. Also, a decrease in soil moisture from $100 \%$ to $30 \%$ in the field enhanced the quantity of amino acid in the grain by $16.6 \%$ and $4.76 \%$ for the organic and inorganic treatments respectively.

Compared to inorganic fertilizer, applying organic fertilizer to wheat in the greenhouse increased amino acid content by $5.96 \%, 9.41 \%$ and $40.9 \%$ for the $30 \%, 60 \%$ and $100 \%$ soil moisture treatments respectively. Whereas, compared to the organic treatment, applying inorganic fertilizer to wheat in the field increased amino acid content by $35.9 \%, 39.8 \%$ and $45.8 \%$, for the $30 \%, 60 \%$ and $100 \%$ moisture treatments respectively.

\section{Concluding Remarks}

The study revealed that elevated levels of soil moisture produced a significant increase in grain yield but in contrast, a decrease in grain amino acid content. Low temperatures at the early vegetative stage marred stem elongation and tillering, while high temperatures at the heading stage hindered panicle growth and grain filling in wheat. The main results of the current work are as follows: 
Wheat treated with inorganic fertilizer and $100 \%$ soil moisture in the greenhouse produced the best yield. Grain amino acid content was dependent on the uptake of mineral nutrient and nutrients uptake was meaningfully related to the amount of soil moisture.

Amino acid accumulation was best for wheat treated with inorganic fertilizer in the field, with decreasing soil moisture than wheat treated with organic and inorganic fertilizers in the greenhouse, and wheat treated with organic fertilizer in the field.

Wheat treated with organic fertilizer and $60 \%$ soil moisture in the greenhouse and wheat treated with inorganic fertilizer and $60 \%$ soil moisture in the field had a balance in yield and protein content.

Author Contributions: Conceptualization, B.E.K.N. and S.-C.L.; methodology, B.E.K.N. and S.-C.L.; software, J.-S.H.; validation, B.E.K.N., J.-S.H. and S.-C.L.; investigation, J.-S.H.; data curation, B.E.K.N. and S.-C.L; writing-original draft preparation, B.E.K.N.; writing-review and editing, B.E.K.N.; supervision, S.-C.L. All authors discussed the results and agreed on the outcome of this manuscript. All authors have read and agreed to the published version of the manuscript.

Funding: This research received no external funding.

Conflicts of Interest: The authors declare no conflict of interest.

\section{References}

1. OECD-FAO. OECD-FAO Agricultural Outlook 2018-2027; OECD Publisher: Paris, France, 2018.

2. Mason, N.M.; Jayne, T.S.; Shiferaw, B. Wheat Consumption in Sub-Saharan Africa: Trends, Drivers, and Implications; International Maize and Wheat Improvement Center: Texcoco, Mexico, 2012; No. 1096-2016-88381.

3. Xiao, D.; Bai, H.; Liu, D.L. Impact of future climate change on wheat production: A simulated case for China's wheat system. Sustainability 2018, 10, 1277. [CrossRef]

4. Coumou, D.; Rahmstorf, S. A decade of weather extremes. Nat. Clim. Chang. 2012, 2, 491-496. [CrossRef]

5. Battisti, D.S.; Naylor, R.L. Historical Warnings of Future Food Insecurity with Unprecedented Seasonal Heat. Science 2009, 323, 240-244. [CrossRef] [PubMed]

6. Godfray, H.C.J.; Beddington, J.R.; Crute, I.R.; Haddad, L.; Lawrence, D.; Muir, J.F.; Pretty, J.; Robinson, S.; Thomas, S.M.; Toulmin, C. Food Security: The Challenge of Feeding 9 Billion People. Science 2010, 327, 812-818. [CrossRef] [PubMed]

7. Rötter, R.P.; Höhn, J.G.; Fronzek, S. Projections of climate change impacts on crop production: A global and a Nordic perspective. Acta Agric. Scand. Sect. A Anim. Sci. 2012, 62, 166-180. [CrossRef]

8. Wang, X.; Li, X. Irrigation water availability and winter wheat abandonment in the North China Plain (NCP): Findings from a case study in Cangxian County of Hebei Province. Sustainability 2018, 10, 354. [CrossRef]

9. Hussain, M.; Shah, S.; Hussain, S.; Iqbal, K. Growth, yield and quality response of three wheat (Triticum aestivum L.) varieties to different levels of N, P and K. Int. J. Agric. Biol. 2002, 4, 362-364.

10. Wadleigh, C.H.; Richards, L.A. Soil Moisture and the Mineral Nutrition of Plants. In Mineral Nutrition of Plants; Truog, E., Ed.; Univ. of Wisconsin Press: Madison, WI, USA, 1951; pp. 411-450.

11. Eppendorfer, W.H.; Bille, S.W.; Patipanawattana, S. Protein quality and amino acid-protein relationships of maize, sorghum and rice grain as influenced by nitrogen, phosphorus, potassium and soil moisture stress. J. Sci. Food Agric. 1985, 36, 453-462. [CrossRef]

12. Raza, S.; Farrukh Saleem, M.; Mustafa Shah, G.; Jamil, M.; Haider Khan, I. Potassium applied under drought improves physiological and nutrient uptake performances of wheat (Triticum aestivun L.). Soil J. Sci. Plant Nutr. 2013, 13, 175-185.

13. Ashraf, M.Y.; Ala, S.A.; Bhatti, A.S. Nutritional imbalance in wheat (Triticum aestivum L.) genotypes grown at soil water stress. Acta Physiol. Plant. 1998, 20, 307-311. [CrossRef]

14. Porter, J.R.; Gawith, M. Temperatures and the growth and development of wheat: A review. Eur. J. Agron. 1999, 10, 23-36. [CrossRef]

15. Fageria, N.K. The Use of Nutrients in Crop Plants; CRC Press: Boca Raton, FL, USA, 2016.

16. Tack, J.; Barkley, A.; Nalley, L.L. Effect of warming temperatures on US wheat yields. Proc. Natl. Acad. Sci. USA 2015, 112, 6931-6936. [CrossRef] [PubMed]

17. He, Y.Q.; Zhu, Y.G.; Smith, S.E.; Smith, F.A. Interactions between soil moisture content and phosphorus supply in spring wheat plants grown in pot culture. Plant J. Nutr. 2002, 25, 913-925. [CrossRef] 
18. Albrizio, R.; Todorovic, M.; Matic, T.; Stellacci, A.M. Comparing the interactive effects of water and nitrogen on durum wheat and barley grown in a Mediterranean environment. Field Crop. Res. 2010, 115, 179-190. [CrossRef]

19. Huang, M.; Dang, T.; Gallichand, J.; Goulet, M. Effect of increased fertilizer applications to wheat crop on soil-water depletion in the Loess Plateau, China. Agric. Water Manag. 2003, 58, 267-278. [CrossRef]

20. Altenbach, S.B.; Dupont, F.M.; Kothari, K.M.; Chan, R.; Johnson, E.L.; Lieu, D. Temperature, Water and Fertilizer Influence the Timing of Key Events During Grain Development in a US Spring Wheat. Cereal J. Sci. 2003, 37, 9-20. [CrossRef]

21. Altenbach, S.B. New insights into the effects of high temperature, drought and post-anthesis fertilizer on wheat grain development. J. Cereal Sci. 2012, 56, 39-50. [CrossRef]

22. Gomez, K.; Gomez, A. Statistical Procedures for Agricultural Research; John Wiley \& Sons: Hoboken, NJ, USA, 1984.

23. Roe, N.E.; Stoffella, P.J.; Graetz, D. Composts from Various Municipal Solid Waste Feedstocks Affect Vegetable Crops. IGrowth, I.; Yields, and Fruit Quality. J. Am. Soc. Hortic. Sci. 2019, 122, 433-437. [CrossRef]

24. Horrigan, L.; Lawrence, R.S.; Walker, P. How sustainable agriculture can address the environmental and human health harms of industrial agriculture. Environ. Health Perspect. 2002, 110, 445-456. [CrossRef]

25. Efthimiadou, A.; Bilalis, D.; Karkanis, A.; Froud-Williams, B. Combined organic/inorganic fertilization enhance soil quality and increased yield, photosynthesis and sustainability of sweet maize crop. Aust. Crop J. Sci. 2010, 4, 722-729.

26. Akram, M. Growth and Yield Components of Wheat Under Water Stress Of Different Growth Stages. Bangladesh J. Agric. Res. 1970, 36, 455-468. [CrossRef]

27. Tavakoli, A.R.; Oweis, T.; Ashrafi, S.; Asadi, H.; Siadat, H.; Liaghat, A. Improving Rainwater Productivity with Supplemental Irrigation in Upper Karkheh River Basin of Iran; International Center for Agricultural Research in the Dry Areas (ICARDA): Aleppo, Syria, 2010; p. 123.

28. Day, L.; Augustin, M.A.; Batey, I.L.; Wrigley, C.W. Wheat-gluten uses and industry needs. Trends Food Sci. Technol. 2006, 17, 82-90. [CrossRef]

29. Campbell, C.A.; Davison, H.R.; Warder, F.G. Effects of fertilizer N and soil moisture on yield, yield components, protein content and $\mathrm{N}$ accumulation in the abovegroud parts of spring wheat. Can. Soil J. Sci. 1977, 57, 311-327. [CrossRef]

30. Dougherty, C.T.; Scott, W.R.; Langer, R.H.M. Effects of sowing rate, irrigation, and nitrogen on the components of yield of spring-sown semi dwarf and standard New Zealand wheats. N. Zeal. J. Agric. Res. 1975, 18, 197-207. [CrossRef]

31. Hou, R.; Ouyang, Z.; Li, Y.; Wilson, G.V.; Li, H. Is the change of winter wheat yield under warming caused by shortened reproductive period? Ecol. Evol. 2012, 2, 2999-3008. [CrossRef] [PubMed]

32. Acevedo, E.; Silva, P.; Silva, H. Wheat Growth and Physiology; Doc. Repos.; FAO Corp.: Roma, Italy, 2009; pp. 1-31.

33. Russell, G.; Wilson, G.W. An Agro-Pedo-Climatological Knowledge-Base of Wheat in Europe; European Commission: Luxembourg, 1994.

34. Tyagi, V.; Singh, R.K.; Nagargade, M. Effect of hydrogel, NPK and irrigation levels on yield, nutrient uptake and water use efficiency of wheat (Triticum aestivum L.). Res. Crop. 2015, 16, 653-656. [CrossRef]

35. Kumar, A.; Sharma, D.; Sharma, H. Growth, yield and water-use efficiency of wheat (Triticum* aestivum) as influenced by irrigation and nitrogen. Indian Agron. J. 1994, 39, 220-224.

36. McDonald, G.K.; Sutton, B.G.; Ellison, F.W. The effect of sowing date, irrigation and cultivar on the growth and yield of wheat in the Namoi River Valley, New South Wales. Irrig. Sci. 1984, 5, 123-135. [CrossRef]

37. Hatfield, J.L.; Boote, K.J.; Kimball, B.A.; Ziska, L.H.; Izaurralde, R.C.; Ort, D.; Thomson, A.M.; Wolfe, D. Climate impacts on agriculture: Implications for crop production. Agron. J. 2011, 103, 351-370. [CrossRef]

38. Chang, J. Climate and Agriculture and Ecological Survey; Chang, J., Ed.; University of Hawaii: Honolulu, HI, USA, 1968.

39. Chakrabarti, B.; Singh, S.D.; Kumar, V.; Harit, R.C.; Misra, S. Growth and yield response of wheat and chickpea crops under high temperature. Indian Plant J. Physiol. 2013, 18, 7-14. [CrossRef]

40. Savin, R.; Slafer, G.A. Developmental base temperature in different phenological phases of wheat (Triticum aestivum). J. Exp. Bot. 1991, 42, 1077-1082. 
41. Coventry, D.R.; Yadav, A.; Poswal, R.S.; Sharma, R.K.; Gupta, R.K.; Chhokar, R.S.; Gill, S.C.; Kumar, V.; Kumar, A.; Mehta, A.; et al. Irrigation and nitrogen scheduling as a requirement for optimising wheat yield and quality in Haryana, India. Field Crop. Res. 2011, 123, 80-88. [CrossRef]

42. Zhao, C.X.; He, M.R.; Wang, Z.L.; Wang, Y.F.; Lin, Q. Effects of different water availability at post-anthesis stage on grain nutrition and quality in strong-gluten winter wheat. C. R. Biol. 2009, 332, 759-764. [CrossRef] [PubMed]

43. Zhongmin, D.; Yanping, Y.; Zhang, M. Starch granule size distribution in wheat grains under irrigated and rainfed conditions. Acta Agron. Sin. 2008.

44. Dubetz, S. Effect of soil type, soil mositure, and nitrogen fertilizer on the growth of spring wheat. Can. Soil J. Sci. 1961, 41, 44-51. [CrossRef]

45. Hutcheon, W.L.; Rennie, D.A. The relation of soil moisture stress and nutrient availability to the growth characteristics and quality of wheat. Trans. 7th int. Congr. Soil Sci. 1960, 3, 488-495.

46. Pleijel, H.; Mortensen, L.; Fuhrer, J.; Ojanperä, K.; Danielsson, H. Grain protein accumulation in relation to grain yield of spring wheat (Triticum aestivum L.) grown in open-top chambers with different concentrations of ozone, carbon dioxide and water availability. Agric. Ecosyst. Environ. 1999, 72, 265-270. [CrossRef]

47. Kibite, S.; Evans, L.E. Causes of negative correlations between grain yield and grain protein concentration in common wheat. Euphytica 1984, 33, 801-810. [CrossRef]

(C) 2020 by the authors. Licensee MDPI, Basel, Switzerland. This article is an open access article distributed under the terms and conditions of the Creative Commons Attribution (CC BY) license (http://creativecommons.org/licenses/by/4.0/). 